\title{
A rehabilitation intervention to promote physical recovery following intensive care: a detailed description of construct development, rationale and content together with proposed taxonomy to capture processes in a randomised controlled trial
}

Pam Ramsay ${ }^{1,2+}$, Lisa G Salisbury ${ }^{2,3^{*+}}$, Judith L Merriweather ${ }^{1,2}$, Guro Huby ${ }^{3}$, Janice E Rattray ${ }^{4}$, Alastair M Hull ${ }^{5}$, Stephen J Brett ${ }^{6}$, Simon J Mackenzie ${ }^{1}$, Gordon D Murray ${ }^{7}$, John F Forbes ${ }^{7}$, and Timothy Simon Walsh ${ }^{2,8}$ on behalf of the RECOVER trial collaboration

\begin{abstract}
Background: Increasing numbers of patients are surviving critical illness, but survival may be associated with a constellation of physical and psychological sequelae that can cause ongoing disability and reduced health-related quality of life. Limited evidence currently exists to guide the optimum structure, timing, and content of rehabilitation programmes. There is a need to both develop and evaluate interventions to support and expedite recovery during the post-ICU discharge period. This paper describes the construct development for a complex rehabilitation intervention intended to promote physical recovery following critical illness. The intervention is currently being evaluated in a randomised trial (ISRCTN09412438; funder Chief Scientists Office, Scotland).

Methods: The intervention was developed using the Medical Research Council (MRC) framework for developing complex healthcare interventions. We ensured representation from a wide variety of stakeholders including content experts from multiple specialties, methodologists, and patient representation. The intervention construct was initially based on literature review, local observational and audit work, qualitative studies with ICU survivors, and brainstorming activities. Iterative refinement was aided by the publication of a National Institute for Health and Care Excellence guideline (No. 83), publicly available patient stories (Healthtalkonline), a stakeholder event in collaboration with the James Lind Alliance, and local piloting. Modelling and further work involved a feasibility trial and development of a novel generic rehabilitation assistant (GRA) role. Several rounds of external peer review during successive funding applications also contributed to development.

(Continued on next page)
\end{abstract}

\footnotetext{
* Correspondence: Lisa.Salisbury@ed.ac.uk

${ }^{\dagger}$ Equal contributors

${ }^{2}$ Edinburgh Critical Care Research group, Edinburgh University and NHS Lothian, Chancellors Building, 49 Little France Crescent, Old Dalkeith Road, Edinburgh EH16 4SB, UK

${ }^{3}$ Interdisciplinary Social Science in Health/Nursing Studies, University of

Edinburgh, Medical School, Teviot Place (Doorway 6), Edinburgh EH8 9AG, UK

Full list of author information is available at the end of the article
} 
(Continued from previous page)

Results: The final construct for the complex intervention involved a dedicated GRA trained to pre-defined competencies across multiple rehabilitation domains (physiotherapy, dietetics, occupational therapy, and speech/ language therapy), with specific training in post-critical illness issues. The intervention was from ICU discharge to 3 months post-discharge, including inpatient and post-hospital discharge elements. Clear strategies to provide information to patients/families were included. A detailed taxonomy was developed to define and describe the processes undertaken, and capture them during the trial. The detailed process measure description, together with a range of patient, health service, and economic outcomes were successfully mapped on to the modified CONSORT recommendations for reporting non-pharmacologic trial interventions.

Conclusions: The MRC complex intervention framework was an effective guide to developing a novel post-ICU rehabilitation intervention. Combining a clearly defined new healthcare role with a detailed taxonomy of process and activity enabled the intervention to be clearly described for the purpose of trial delivery and reporting. These data will be useful when interpreting the results of the randomised trial, will increase internal and external trial validity, and help others implement the intervention if the intervention proves clinically and cost effective.

Keywords: Critical care, Rehabilitation, Complex intervention

\section{Background}

Survival following critical illness can be associated with a constellation of physical, psychosocial and cognitive impairments that result in disability and reduced healthrelated quality of life (HRQoL) [1-4]. Prevalent issues include weakness, fatigue, breathlessness, poor nutritional state, anxiety, depression, post-traumatic reactions, and reduced cognitive function [1,5-9]. Many patients are unable to perform instrumental activities of daily living (ADLs), are slow or fail to return to employment, and require significant functional and psychosocial support from family members [10-13]. The economic implications of postcritical illness disability are poorly defined, but are likely to be high in terms of direct and indirect healthcare costs [14-16]. Observational studies have identified and quantified many aspects of post-critical illness disability, but there are few evaluations of rehabilitation interventions designed to support or expedite recovery. Published clinical trials suggest possible improvement in physical recovery from strategies that promote early mobilisation and muscle activity during intensive care [17-19], and the supervised use of a self-help manual in the early post-ICU period improved recovery of physical HRQoL scores [20]. In contrast, other strategies focussing on longer-term physical recovery through physiotherapy and exercise programmes, and follow up clinics, have not improved clinical outcomes [21-23].

Rehabilitation is a complex healthcare intervention, usually involving multiple components delivered by a range of healthcare professionals. Complexity is increased when the patients involved are heterogeneous in terms of impairment types, severity, concurrent comorbidity and when the trajectories of recovery vary. In addition, different impairments may interact in variable ways, which may affect the response to therapeutic interventions [24-26].
Studying post-critical illness rehabilitation is therefore highly complex. Failure of an intervention could occur because the components were ineffective, because they were not delivered as intended, or because other factors limited their impact (for example, psychological morbidity or patient inability to participate due to fatigue). It is also possible that improvements in important outcomes are missed if the measures used lack sensitivity or are measured at the wrong time [27].

The development and evaluation of complex healthcare interventions requires an alternative approach to that used for simple interventions such as novel drugs. The Medical Research Council (MRC) has published guidance on development, evaluation, and reporting, which recommends addressing the following questions when developing an intervention [27]:

- Are you clear about what you are trying to do, what outcome you are aiming for, and how you will bring about change?

- Does your intervention have a coherent theoretical basis which has been used to develop the intervention?

- Can you describe the intervention fully, so that it can be implemented properly for the purposes of your evaluation, and replicated by others?

- Does the existing evidence suggest that it is likely to be effective or cost effective?

- Can it be implemented in a research setting, and is it likely to be widely implementable if the results are favourable?

The extended CONSORT guidance for reporting nonpharmacologic randomised trials emphasises the need to fully describe interventions [28]. Specifically, rehabilitation 
trials should report the content of therapy sessions, how they were delivered, the information exchanged with participants, and the instruments used to provide information. Data describing the number, timing, and duration of each therapy session, its main component(s), and the overall duration of the intervention should be described, and it is recommended that the ways in which the intervention was tailored to individual patient needs is reported. Wells and colleagues [29] emphasised the importance of describing and understanding context in complex intervention trials to maximise understanding of the external relevance of findings outwith trial settings.

We developed a complex healthcare intervention to promote physical recovery following critical illness, which is currently being evaluated in a randomised trial: the RECOVER study (ISRCTN09412438). The trial protocol has been published [30]. The aim of this paper is to describe how the RECOVER intervention was developed and present a taxonomy for describing the treatments delivered. The information included is intended to enable other clinicians, researchers, and healthcare providers to fully understand the rationale for the intervention. We anticipate this will improve the external validity of the trial findings by providing a level of information that will help interpret the findings. The detail provided in this paper will aid reproduction of the intervention in other settings.

\section{Methods}

The intervention evolved between 2005 and 2010. The multidisciplinary research group included an academic critical care physician (TSW), two academic ICU nurses (PR, JER), an academic physiotherapist (LGS), a clinically and research active dietitian (JLM), a psychiatrist with an interest in post-critical care psychological morbidity $(\mathrm{AMH})$ and a critical care physician in a senior National Health Service (NHS) management role (SJM). Methodologists included a social anthropologist with expertise in health service change (GH), a trialist/statisticians (GDM, Steff Lewis (MRC methodology hub; Edinburgh University) and a health economist (John Forbes (Centre for Population Health Sciences, Edinburgh University)).

The optimum methodology for developing rehabilitation trials for patients experiencing critical illness has not been determined, and we did not define this a priori at the start of the research programme. The process used was iterative and a range of factors influenced the final construct, including responses to reviewers during sequential revisions of grant applications. Individual and collective brainstorming strongly influenced the final intervention, which was also influenced by emerging local data from collaborators undertaking post-graduate degrees and post-doctoral work during this period [31-33]. These individuals adopted lead roles in defining specific elements of the intervention, but group activities ensured all ideas were heard.
Inputs from patients and carers were collated from several sources: first, a local qualitative study with survivors of prolonged mechanical ventilation [31]; second, discussions with former patients during a "pilot" post-ICU service (see below); third, a range of interviews publicly available at Healthtalkonline (http://healthtalkonline.org); fourth, a James Lind Alliance event organised by the Edinburgh Critical Care Research Group at which the perceived needs of patients during the post-ICU period was discussed [34]; and fifth, a patient representative on the trial steering group, who had experienced a prolonged recovery following severe acute respiratory distress syndrome.

During the iterative development process it became clear that defining the content of the intervention, its timing in relation to the recovery process, and the method of delivering it were of central importance to both trial design and subsequent interpretation of findings. These are each considered separately. Following agreement of the final construct, a taxonomy was developed to fully describe the intervention components, and facilitate adequate reporting during the trial.

\section{Results}

\section{Defining components of the intervention}

The range of research, feasibility, and piloting activities that contributed to defining the intervention content are summarised below.

\section{Literature review}

We undertook a detailed literature review, which indicated consistent reports of physical disability after ICU discharge, which was most marked in the initial months and tended to recover with variable trajectories over 3 to 6 months $[1,35,36]$. Many patients did not regain pre-illness function. It was also relevant that many patients report pre-existing comorbidity and physical impairment [37-40]. Poor appetite and altered taste were widely reported, which could contribute to slow nutritional recovery and/or failure to regain pre-illness weight [5]. The published literature suggested these features are most prominent during the initial weeks and months following ICU discharge, corresponding to the period in hospital and early after discharge to community/primary care. However, the duration of symptoms and disability clearly vary widely between individuals in type, severity and duration, and no validated method for predicting individual recovery trajectories was found.

In addition to physical disability, a high prevalence of psychological morbidity following critical illness was reported $[6,7,9,36,41-43]$. This included anxiety, depression, and post-traumatic stress symptomatology with widely ranging prevalence depending on case mix, time of measurement, and measurement tool [43]. Emerging evidence 
over the development period suggested symptomatology was increased by pre-illness factors (for example, previous psychiatric history) [6,41], a mixture of non-modifiable and potentially modifiable ICU related factors (greater illness severity, delusional memories, delirium, oversedation) $[41,44]$, and potentially modifiable post-ICU factors (provision of information, patient diaries) [45,46]. In addition to psychological morbidity, the literature indicated significant cognitive decline in many patients following critical illness, including impaired memory, executive function $[9,47,48]$ and limitation in instrumental ADLs $[38,47]$. There were few published trials of therapeutic interventions over the course of intervention development. Many of these were restricted to the time in ICU. Several studies strongly influenced the development of our intervention (Table 1).

During intervention development, the National Institute for Health and Care Excellence (NICE) published a short guideline for rehabilitation after critical illness [36]. This included a formal systematic review and recommendations based substantially on the multidisciplinary expertise of the guideline development group (GDG). The systematic review did not identify important new evidence compared to our literature review. The GDG recommended sequential assessments at key points in the patient pathway, with provision of physical and psychological rehabilitation when appropriate. The GDG acknowledged, however, that the most appropriate assessment tools and rehabilitation interventions were unknown. A summary of the key recommendations is shown in Table 2. To ensure our intervention was consistent with the recommendations and expertise of the GDG we invited the Chair (SJB) to act as independent Chair to the RECOVER Trial Steering Committee, offering advice and additional expert review.

\section{Work with patients and families}

Qualitative interviews with former patients [31] indicated a range of important issues during the weeks following
ICU discharge that were important to patients. Thematic analysis resulted in key issues to incorporate in the trial intervention (Table 3). Some were generic (for example, coordination and continuity of care, preparation for discharge home, providing information) while others related to specific issues (for example, physiotherapy provision, individualised therapy, discussion of memories). Many of these were supported by existing literature, and were also reported by patients and families during discussions at the James Lind Alliance event [34].

\section{Audit of existing service provision}

To provide additional local data, we prospectively audited current provision of rehabilitation between ICU and hospital discharge in one institution (Royal Infirmary of Edinburgh, Scotland), with a focus on the level of input in terms of physiotherapy, dietetic, and other allied health services [32]. We noted that physiotherapy sessions were of low frequency and intensity and limited range. Dietetic management was limited to review of nutritional status and requirements, and advice about artificial nutrition or provision of supplements. Follow-up to explore whether nutrition was improved (for example, through food diaries, monitoring intake of supplements, assisting with eating, or individualisation of food provision) was rarely achieved. Systematic use of referral triggers to rehabilitation specialists such as occupational therapy and speech and language therapy was absent. Those referrals which did occur did so in an ad hoc manner. Many patients were not assessed or reviewed by these specialists until close to hospital discharge. Important general observations were that patients discharged from critical care became widely dispersed across the general wards, usually according to their "parent" specialist team. This resulted in a dilution of knowledge and expertise among medical, nursing and allied health professional staff of their history and problems, which affected continuity of care. A striking observation was that large numbers of different healthcare professionals reviewed patients at different times often in an

Table 1 Rehabilitation trials after critical illness that strongly influenced the intervention development

\begin{tabular}{ll}
\hline Trial & Summary \\
\hline Jones et al. 2003 [20] & Ward-based: Self-help manual over 6 weeks, which improved physical function (measured using the SF-36 PCS) at 2 \\
& $\begin{array}{l}\text { and } 6 \text { months following ICU discharge. Patients were recruited to the study within } 1 \text { week of discharge from } \\
\text { intensive care. The intervention group received the self-help manual in addition to the routine ICU follow-up that all } \\
\text { patients received. }\end{array}$
\end{tabular}

Schweickert et al. 2009 [49] Intensive Care: Early exercise and mobilisation (physical and occupational therapy) during sedation breaks in intensive care. Patients were recruited if less than 72 hours of mechanical ventilation. Return to independent functional status at hospital discharge was significantly higher in the intervention group. They also had a shorter duration of delirium and more ventilator-free days compared to the standard care group. The intervention was delivered primarily in the ICU.

Cuthbertson et al. 2009

Discharge Home: Nurse-led follow-up clinic at 3 and 9 months post-hospital discharge, in combination with a (PRaCTICaL) [21] manual based, self-directed, physical rehabilitation programme introduced in hospital. At 12 months, there were no statistically significant differences in HRQoL or any secondary measures between groups. 
Table 2 Summary of recommendations from National Institute for Health and Care Excellence clinical guideline 83

\begin{tabular}{|c|c|}
\hline General recommendations & $\begin{array}{l}\text { Rehabilitation should be undertaken by individuals with relevant skills and knowledge } \\
\text { communication between teams and professionals over the rehabilitation pathway should occur }\end{array}$ \\
\hline \multicolumn{2}{|l|}{$\begin{array}{l}\text { Pathway-specific } \\
\text { recommendations }\end{array}$} \\
\hline \multirow[t]{5}{*}{ During critical care stay } & Assess risk of post-ICU disability \\
\hline & Commence goal-oriented rehabilitation early \\
\hline & Involve families and carers \\
\hline & Provide illness-related information to patient and family \\
\hline & Optimise provision of nutrition \\
\hline \multirow[t]{3}{*}{ At ICU discharge } & Screen patient for physical and psychological issues \\
\hline & Plan individualised rehabilitation programme with defined goals \\
\hline & $\begin{array}{l}\text { Provide information to patients and families about rehabilitation pathway, likely morbidity, ICU stay, and transition to } \\
\text { general ward environment }\end{array}$ \\
\hline \multirow[t]{4}{*}{ During ward based care } & Repeat screening for physical and psychological issues \\
\hline & Offer individualised rehabilitation programme with defined goals, provided by a multidisciplinary team \\
\hline & Regularly update rehabilitation programme and goals, making specialist referral where appropriate \\
\hline & Offer structured self-directed and supported rehabilitation manual for at least 6 weeks to appropriate patients \\
\hline \multirow[t]{3}{*}{ Prior to hospital discharge } & $\begin{array}{l}\text { Perform a functional assessment including physical and psychological elements, evaluating the impact on patient } \\
\text { activities of daily living and participation }\end{array}$ \\
\hline & Ensure support for outstanding issues are arranged, including ongoing rehabilitation by community services \\
\hline & Provide patient and family with relevant information, including information about their ICU stay \\
\hline \multirow{2}{*}{$\begin{array}{l}\text { At } 2-3 \text { months post-ICU } \\
\text { discharge }\end{array}$} & Review patient as outpatient and perform functional assessment \\
\hline & Refer for ongoing rehabilitation and/or specialist support according to individual need \\
\hline Adapted from [36] & \\
\hline
\end{tabular}

uncoordinated manner [33]. Few professionals had time to gain an understanding of complex histories and clinical course of patients. In addition, patients effectively "competed" with less severely unwell patients (for example, elective surgery or short-term medical admissions) for scarce rehabilitation resource. There was an impression that shortages of ward beds potentially resulted in prioritisation of less sick patients for rehabilitative provision because they were more likely to be discharged quickly. Post-ICU patients were usually discharged directly home, were rarely offered formal rehabilitation, and when this occurred there was usually a long delay in transfer. Hospital discharge planning was poorly coordinated and the information provided to general practitioners and other community staff was inconsistent and often incomplete.

\section{Pilot provision of post-ICU rehabilitation multidisciplinary ward round}

Two ICU consultants (including TSW) piloted a multidisciplinary weekly round of patients who spent $>4$ days in the ICU with members of the research team representing a nursing (PR), dietetic (JLM), and physiotherapy (LGS) perspective. A log was kept to capture key contributions that might be incorporated in the trial intervention.
Several additional issues emerged from this work: first, patients and families had limited access to information about the ICU stay or likely recovery trajectory from medical, nursing or other staff; second, review of medical notes often revealed medication changes that were overlooked (for example, stopping stress ulcer prophylaxis, antibiotic review, re-starting usual medications); third, patients were frequently socially isolated (often placed in a side room) because of real or perceived infection risk (for example, MRSA colonisation) or debility; fourth, patients frequently had prominent traumatic delusional memories that were not being aired, they did not understand, and were often only revealed when questioned sensitively; fifth, the information provided to community teams was often medicalised and not relevant to the rehabilitation needs of the patient; sixth, the demands and workload of the multidisciplinary team on general wards, especially nursing, dietetic, physiotherapy, and medical staff, meant they rarely met together to coordinate case management of complex post-ICU patients; finally, decisions about hospital discharge were often determined by medical staff from the 'parent speciality' team without multidisciplinary planning or negotiation with individual patients and/or their family members. 
Table 3 Key themes from interviews with survivors of critical illness

Theme
Coming to terms with memories and experience of ICU
Needing knowledge and information
- Waking up and not knowing what has happened
for flexibility in terms of timing
- Poor continuity of care/inability of ward-based staff to
provide information on the critical illness event

\section{Dealing with physical disability}

- Making sense of functional impairment and dependence

- Frustration with brevity, frequency, delivery of physical therapy in relation to perceived needs

- Regaining functional independence as priority

- Feeling outside the rehabilitative process

\section{General ward staff awareness}

- Perceived insensitivity of staff to limitations and basic care needs

- Lack of understanding of their limitations and its cause (ICU-acquired weakness)

\section{Hospital discharge planning}

- Pressure on beds; patients often discharged with limited functional ability

- Poor communication between acute and community teams; lack of timely provision of home aids

\section{Early life at home}

- Not being adequately prepared for dependence on others

- Lack of guidance in terms of self-management of the recovery process

\section{Illustrative quotes}

"I was convinced that Jack (the Ripper) was going to... slit my throat, that he'd killed 2 nurses and he'd dumped their bodies in a bin down the side of the stairs. It really was frightening".

"... it all just suddenly clicked into place... it suddenly became a hospital. I suppose I was...getting the drugs out of my system. Certainly, those first days, I was in the twilight zone..."

"I said, "Tell me once I'm better. Don't tell me just now, because every day is a battle". I really didn't want to hear... how close to death I'd been".

"Even in my fuzzed head, I was aware on a number of occasions that whoever was momentarily in charge of me had scant knowledge of who I was and how I got there".

"I don't know if it's something that happens if you've only been in [ICU] a few days... but your body feeds off your muscles. I didn't know any of this... Had I have had this knowledge, it would've been...easier for me to accept".

"I was told I'd get very intensive physio... and then I got none for 5 days straight. It was only when I made a fuss that I got it. And then I got...just a list of things to do on my own...that were way beyond my capabilities".

"I'd get maybe 10 minutes of physiotherapy every day. Eventually. It wasn't particularly aggressive physiotherapy... being hoisted up in a stand aid, and sitting down again. In terms of getting you back on your feet, it was minimal".

"I was determined I was gonna get mobile as quick as possible. I've got that determination. I've had it all my life".

"I had to fight with them at first, but then they let me do things at my own pace. I said to them "I will walk and I will do this, but you've got to let me do it...my own way".

"I had to get some assistance having a seated shower. I couldn't stand because I was so weak... and they maybe showed a bit of impatience with me there".

"I said, "I never should've been left the way I was. I should've done exercises so that I wasn't in this state." And Dr Charmless said to me, "Well, that can't be helped".

"When I first got home, I got the shock of my life... I could put water in the kettle, but I couldn't lift it. That's when you say to yourself, "You are bad".

"I'm still waiting (for a bath seat), and I don't know whether to ring back or persevere. Maybe somebody's need is greater than mine. But initially, it would've been a big help".

"I was glad to be home but very, very tired and very weak. I had to rely on someone to help me get up, dress me, that sort of thing".

"I could've done more...to help myself... because my brother asked for a sheet of exercises for me to do when I got out. I realise now... I could've been doing a lot of that... and I think I could've progressed quicker".

"... one afternoon, I walked right over there (gestures out of the window). But I was so knackered later that day that I daren't go out the next day at all. At first I thought, "Oh, I'll perhaps do this every day", but I've not been out since (laughs)".

\section{Feasibility trial to deliver enhanced physical and dietetic therapy with a generic rehabilitation assistant}

A single-centre feasibility trial was undertaken to explore whether a GRA could work effectively under the supervision of multiple existing specialist teams to improve access to rehabilitation, coordinate case management, and deliver therapy. The results of this trial have been published, together with an individual case study $[32,33]$. This study established a model for a GRA with multiple skills working across several teams (primarily physiotherapy) under senior supervision. It also enabled the educational requirements of the role to be identified and developed, competencies defined, and the development of trigger tools for referral to senior specialists. 
The study specifically highlighted the need for pacing and individualised patient-centred goal setting techniques for both dietetic and physiotherapy rehabilitation. The high levels of fatigue immediately following intensive care discharge and wide variation in ability between patients highlighted the need for individually tailored rehabilitation programmes.

\section{Selection of key intervention elements}

Based on the above, we decided to focus our intervention primarily on physical rehabilitation, because physical impairments were highly prevalent, appeared to strongly influence length of acute hospital stay, and profoundly affected the lives/ADLs and HRQoL of patients. The intervention components focussed primarily on better coordination and increased delivery of physiotherapy and nutritional rehabilitation, with a clear strategy to engage occupational therapy and speech and language therapy when required. An emphasis was placed on individualised rehabilitation to suit patient ability, with the intention of including patient-centred goal setting to the rehabilitation process. The only post-ICU intervention with evidence of effectiveness from clinical trials was the use of a self-help manual [20], so we chose to provide these to all participants, irrespective of group allocation in the trial. Our intention was for the standard care group to receive these in the context of existing rehabilitation services, whereas the intervention group would receive them as part of their enhanced rehabilitation.

Physical rehabilitation was supplemented by information giving in the form of a consultant visit, lay summary, and the offer of an ICU visit. These interventions focussed on explanation of events during ICU admission, current symptomatology (including delusional memories), and what to expect during recovery.

We recognised the importance of psychological morbidity to recovery. From the content experts in our group (AMH and JER), it was clear that the progression and evolution of psychological symptomatology is difficult to predict, and that evidence for the optimum intervention, its timing, and efficacy are very uncertain during the early recovery period. We therefore chose to provide enhanced information provision as part of the intervention, educate staff in the principles of post-ICU psychological problems, but not include a formal psychological intervention.

\section{Timing of the intervention}

We decided to focus our intervention from the time of ICU discharge for up to 3 months, when the primary outcome of physical function was measured. Evidence for benefit from early physical mobilisation during mechanical ventilation emerged during the intervention development [49-51], and was being progressively implemented as a standard of care in the participating
ICUs. In addition, the NICE guidance made research recommendations to evaluate the impact of coordinated rehabilitation, and the impact of specific therapeutic components, at key stages of recovery [36]. We decided to exclude the ICU stay, because this treatment would be difficult to control and the focus of our intervention was multidisciplinary rehabilitation during the later stages of recovery. In the UK, where the trial was planned, most patients are discharged to general ward care within a short time of discontinuing mechanical ventilation and other organ support (typically 1 to 2 days). On a practical level, recruiting patients earlier during mechanical ventilation introduced the competing risk of death as a potential major problem with trial design, because hospital mortality for patients requiring $>48$ hours of mechanical ventilation is typically 20 to $25 \%$ [52]. This was potentially problematic where the proposed primary and important secondary outcomes were measures of disability and HRQoL. Pragmatically, we thought the complexity of delivering and describing a multidiscipinary complex intervention during and after ICU, two environments with very different implementation challenges, would increase the risk of unsuccessful project completion. The entry point was therefore the time a patient was deemed fit for discharge from the ICU by the responsible physician.

We chose to end the period of intervention at 3 months post-randomisation irrespective of patient status or location. Our rationale was that the steepest trajectory of physical recovery occurs during this period, but the literature clearly indicates persisting disability among many patients at this time point $[1,3,4,53]$. We expected this intervention period to include the transition to general ward care for all patients, the full period of general ward care for the majority of patients, the transition to postacute hospital destination for the majority of patients, and a period of living at home or other post-discharge placement for most patients (Figure 1). As such, our intervention period included the key areas of need identified during development; it was clearly defined for the purpose of trial design and reporting. Previous studies have used hospital discharge as the outcome assessment point, which is influenced by factors other than disability, and is potentially subject to researcher bias in non-blinded trials $[49,51]$. We chose not to include clinical review at 2 to 3 months as part of the intervention. This decision was influenced by the negative results of a high-quality trial of ICU follow-up clinics [21], the limitations of what could be achieved with available resources, and the pre-trial qualitative and audit data indicating the high unmet needs during the first 3 months following ICU discharge.

\section{Method for delivering the intervention}

We decided to employ dedicated GRAs as the key structure underpinning our intervention, extending the role 


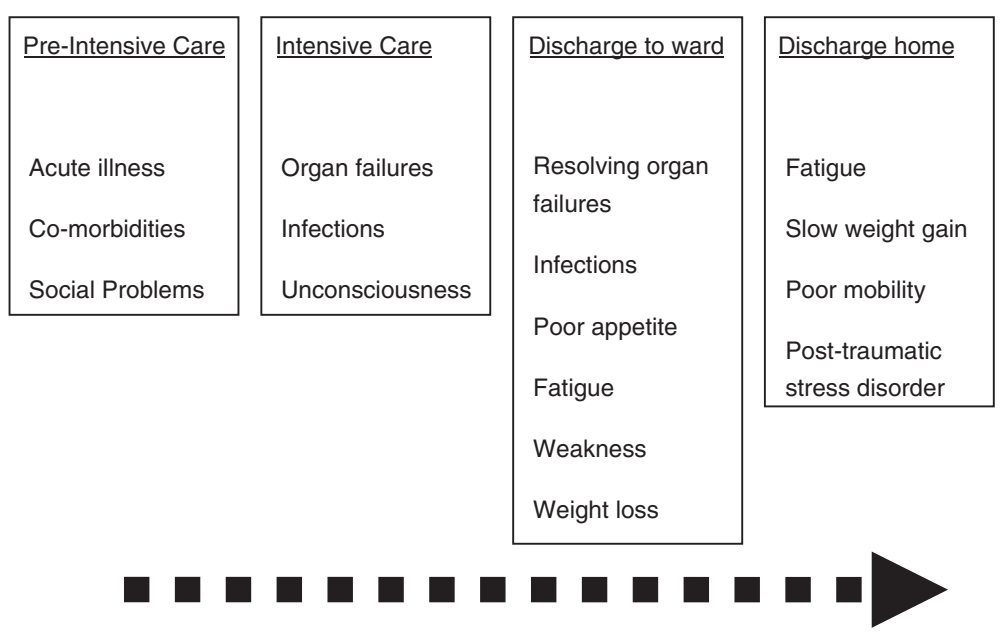

Fragmented pathway

Service centred not patient centred

Figure 1 Critical illness pathway with key stages of recovery and transitions of care.

from our feasibility trial [32]. We used the feasibility trial and audit data to anticipate the number of GRAs required across the two participating hospitals (2.5 whole-time equivalents; three individuals). The salaries for these individuals was identified as an additional treatment cost for the purpose of economic evaluation, and specific appointments to the posts were made by interview using an agreed job specification (available on request). We developed a clear educational content and competencies across physiotherapy, dietetics, occupational therapy, and speech/language therapy. The GRAs were trained according to these prior to starting the trial during a 1-month programme that included general education about critical illness and recognition of psychological issues after intensive care. A description of the training programme is included in Additional file 1. We developed a comprehensive competency document covering generic and discipline-specific skills required by the GRAs for this post. Individual competencies were assessed by qualified health professionals from the relevant disciplines. GRAs were given the opportunity to observe new skills and undertake them with supervision before they were deemed competent. This process is now being formalised further with the adoption of the Calderdale Framework [54]. We planned to embed these individuals in existing NHS teams, but limited their clinical activity to patients randomised to the intervention group. This was important to protect time to ensure delivery of the intervention as intended, and also minimised or eliminated various form of bias that are problematic in rehabilitation studies, including crossover effects, performance bias, differential expertise bias, instruction bias, and bias in using screening tools [28]. It also reduced but could not eliminate the impact of learning and experience during the course of the trial.

\section{Final construct and taxonomy}

The final construct was agreed by a process of consensus, iteratively incorporating all of the data sources described above as they became available. The final peer review was by the Trial Steering Committee prior to submitting the final protocol for approval. Importantly, this included the independent Chair (SJB, a critical care clinician and chair of the NICE 83 GDG), a patient representative (a survivor of prolonged critical illness), and two independent content experts (a consultant and clinical manager of a medicine of the elderly service; and a consultant in rehabilitation medicine). In defining the final construct, we established a clear taxonomy to describe what was intended to occur, aiming to use this to structure the collection of process data during the trial. Wherever possible, we incorporated recommendations made in the MRC [27] and modified CONSORT guidance [28], anticipating that reporting would clearly describe what was done during the trial for both intervention and usual care groups. The parts of the patient pathway targeted by our final construct were discharge to the ward, during the acute hospital ward phase, at discharge from acute hospital, and after discharge home via telephone support (Figure 1). These included three of the five key stages identified in NICE guidance, namely ICU discharge, during ward-based care, and at discharge home (excluding during intensive care stay and formal follow-up at 2 to 3 months following hospital discharge).

The key elements of our complex intervention, their timing, frequency, healthcare workers involved, training of individuals delivering the intervention, fixed versus 
flexible elements, and degree of participation required from patients for successful delivery are shown in Table 4. This structure was adapted from suggestions by Wells and colleagues [29] to maximise information about the dimensions and context of the complex intervention. Adequate description of how the intervention was actually implemented and received by patients was expected to be vital to the internal and external validity of the findings, and interpretation of results. We incorporated processes that were identifiable, quantifiable and directly comparable into a process evaluation, which was included in the trial analysis plan. Key trial materials that operationalized the intervention, including the GRA education programme, the trigger tools used by GRAs for senior referral, the topic guides used for the consultant meeting, examples of the lay summary, the patient-centred goal-setting sheet and the discharge information letter sent to general practitioners by the GRAs are all included in Additional file 1. The trial analysis plan (which included the process evaluation plan) is available with the published protocol [30].

\section{Discussion}

We have provided a detailed account of the development of a complex rehabilitation intervention during the first 3 months following ICU discharge. In reflecting on this process, it is useful to consider whether the questions set out in the MRC complex intervention guidance were addressed during the construct development [27].

Interventions to improve recovery from critical illness could be developed to improve specific impairments (for example, leg muscle strength), specific functions (for example, ability to carry out ADLs), or specific symptoms (for example, fatigue). In practice, effective interventions are likely to affect multiple aspects of disability, including structure, function, activity, and participation domains [55], and may interact differently between patients. The intervention we describe will change care through a combination of new service development, specifically trained GRAs, and enhanced coordinated therapy across multiple rehabilitation domains. A methodological advantage of this model will be a reduced chance of bias and cross-over effects when comparing data to the parallel usual care group in the trial. In response to the perceived need for information a clear strategy to provide this will be included. We have therefore developed an intervention strategy with clearly defined components, timing, and a delivery model to implement the change.

We drew upon existing literature, a NICE guideline [36], qualitative work [31], and local data $[32,33]$ to develop our construct and the rationale underpinning each component. Importantly, our construct was developed over a 5-year period with multiple episodes of iterative revision based on experience, internal and external review, and input from a wide range of relevant content experts and methodologists from different clinical and academic perspectives. We also engaged with patients and their families. We therefore believe that the final intervention is well supported by relevant evidence, and the plausibility of it translating into improved physical recovery, improvements in a range of other secondary outcomes, and an improved patient experience is high.

We have exerted significant effort to describe what we intend to do and a taxonomy to record and describe what actually happens in our trial. In referring heavily to the extended CONSORT guidance for reporting trials of nonpharmacologic interventions [28], we believe we will be able to address most checklist items when we report our findings. Specifically, as recommended for rehabilitation trials, we will describe numbers and timing of sessions, data on individual components of the intervention, the overall duration of different treatments, and when treatments will be tailored to individuals. The effort and resource required to provide this level of description during the trial is very substantial, but should enable detailed assessment of the key treatments that contribute to any effects observed. This detailed process evaluation will enable others to understand and implement the intervention if it is clinically effective. Importantly, it will also allow a clear description of the level of enhanced therapy that was not effective if results are negative, and clearly describe the usual care therapy that generated similar outcomes. This will be important for comparison with previous and future trials.

Existing evidence clearly indicates the need for novel approaches to rehabilitate patients after critical illness, because current disability levels are high in both physical and mental health domains $[1,3,4,35]$. A small randomised controlled trial published during development of our trial found improved functional outcomes in medical patients in whom an early mobilisation strategy was implemented during ICU care, compared with a usual care group receiving very limited mobilisation [49]. Recent systematic reviews of all published trials suggest mobilisation is important for recovery, although the quality of evidence is low [17-19]. These studies provide strong plausibility that an intervention coordinating enhanced physical, dietetic, and other rehabilitation will improve patient outcomes over the 3-month period following ICU discharge. We recently conducted a systematic review of costs following critical illness, but found few cost-effectiveness studies, high levels of heterogeneity, and wide variability in cost [16]. Despite variability, overall direct healthcare costs are high as the main determinant of cost is inpatient hospital stay. Analysis of potential cost-effectiveness of post-critical illness rehabilitation undertaken as part of the NICE guideline 83 [36] suggested that clinically effective interventions are very likely to be cost-effective [56]. Our 
Table 4 Detailed description of the rehabilitation construct adapted from recommendations from wells and colleagues [29], the Medical Research Council framework [27], and the modified CONSORT guidance for randomised controlled trials of non-pharmacologic randomised controlled trials [28]

\begin{tabular}{|c|c|c|c|c|c|c|c|c|c|c|}
\hline $\begin{array}{l}\text { Stage of } \\
\text { patient } \\
\text { pathway }\end{array}$ & $\begin{array}{l}\text { Component of } \\
\text { intervention }\end{array}$ & purpose & $\begin{array}{l}\text { Structure and } \\
\text { components }\end{array}$ & Theory/rationale & $\begin{array}{l}\text { Flexibility to } \\
\text { individual } \\
\text { patient }\end{array}$ & $\begin{array}{l}\text { Degree of } \\
\text { active patient } \\
\text { participation } \\
\text { required }\end{array}$ & $\begin{array}{l}\text { Healthcare } \\
\text { professionals } \\
\text { involved }\end{array}$ & $\begin{array}{l}\text { Attributes and } \\
\text { relevant training } \\
\text { of healthcare } \\
\text { professional }\end{array}$ & Location & Timing \\
\hline \multirow[t]{7}{*}{$\begin{array}{l}\text { Stage one - } \\
\text { ICU } \\
\text { discharge }\end{array}$} & $\begin{array}{l}\text { Introduction of } \\
\text { patient to GRA, } \\
\text { initial } \\
\text { assessment, and } \\
\text { explanation of } \\
\text { rehabilitation } \\
\text { strategy }\end{array}$ & $\begin{array}{l}\text { To establish } \\
\text { relationship } \\
\text { between GRA } \\
\text { and patient }\end{array}$ & Initial meeting & $\begin{array}{l}\text { Early commitment to } \\
\text { provide individualised } \\
\text { rehabilitation and } \\
\text { information will } \\
\text { promote engagement, } \\
\text { trust and reassurance, } \\
\text { and reduce perception } \\
\text { of abandonment }\end{array}$ & Low & Low & $\begin{array}{l}\text { GRAs together } \\
\text { with existing } \\
\text { rehabilitation } \\
\text { teams } \\
\text { (primarily } \\
\text { physiotherapy } \\
\text { and dietetics) }\end{array}$ & $\begin{array}{l}\text { GRA competency- } \\
\text { based training in } \\
\text { assessment and } \\
\text { awareness of } \\
\text { common ICU } \\
\text { problems }\end{array}$ & $\begin{array}{l}\text { General ward; } \\
\text { occasionally in } \\
\text { the ICU prior } \\
\text { to discharge }\end{array}$ & $\begin{array}{l}\text { As soon as } \\
\text { feasible } \\
\text { following } \\
\text { allocation to } \\
\text { intervention } \\
\text { group }\end{array}$ \\
\hline & & $\begin{array}{l}\text { Provide } \\
\text { information to } \\
\text { patient and } \\
\text { carer }\end{array}$ & $\begin{array}{l}\text { Formal } \\
\text { assessment of } \\
\text { function }\end{array}$ & & $\begin{array}{l}\text { Timing to suit } \\
\text { patient, but } \\
\text { within } 1 \text { day } \\
\text { of } \\
\text { randomisation } \\
\text { in most cases }\end{array}$ & & & & & \\
\hline & & & $\begin{array}{l}\text { Setting initial } \\
\text { rehabilitation } \\
\text { goals }\end{array}$ & & & & & & & \\
\hline & $\begin{array}{l}\text { Meeting } \\
\text { between } \\
\text { patient and ICU } \\
\text { consultant, with } \\
\text { involvement of } \\
\text { GRA and family } \\
\text { where } \\
\text { appropriate }\end{array}$ & $\begin{array}{l}\text { To provide } \\
\text { information } \\
\text { about ICU stay } \\
\text { and likely } \\
\text { problems during } \\
\text { recovery }\end{array}$ & $\begin{array}{l}\text { Scheduled } \\
\text { meeting }\end{array}$ & $\begin{array}{l}\text { Information will reduce } \\
\text { stress and anxiety }\end{array}$ & Moderate & Moderate & $\begin{array}{l}\text { ICU } \\
\text { consultant. }\end{array}$ & $\begin{array}{l}\text { ICU consultant } \\
\text { familiar with topic } \\
\text { guide, knowledge } \\
\text { of generic post- } \\
\text { ICU issues and the } \\
\text { individual patient } \\
\text { history }\end{array}$ & General ward & $\begin{array}{l}\text { During the first } \\
\text { week or when } \\
\text { deemed most } \\
\text { appropriate by } \\
\text { the GRA }\end{array}$ \\
\hline & & $\begin{array}{l}\text { Opportunity for } \\
\text { patients and } \\
\text { family to ask } \\
\text { questions }\end{array}$ & $\begin{array}{l}\text { Topic guided } \\
\text { discussion to } \\
\text { cover physical } \\
\text { and } \\
\text { psychological } \\
\text { sequelae of } \\
\text { critical illness' }\end{array}$ & $\begin{array}{l}\text { Filling in gaps and } \\
\text { exploring delusional } \\
\text { memories may reduce } \\
\text { psychological } \\
\text { morbidity }\end{array}$ & $\begin{array}{l}\text { Optional; } \\
\text { patient may } \\
\text { decline } \\
\text { meeting }\end{array}$ & & $\begin{array}{l}\text { Meeting } \\
\text { usually } \\
\text { attended by } \\
\text { GRA }\end{array}$ & & & \\
\hline & & & & $\begin{array}{l}\text { Answering questions } \\
\text { and providing realistic } \\
\text { expectations may help } \\
\text { adjustment }\end{array}$ & $\begin{array}{l}\text { Meeting } \\
\text { tailored to } \\
\text { individual } \\
\text { patient and } \\
\text { family }\end{array}$ & & & & & \\
\hline & $\begin{array}{l}\text { Provision of lay } \\
\text { summary of } \\
\text { ICU stay }\end{array}$ & $\begin{array}{l}\text { Provide } \\
\text { information } \\
\text { about ICU stay } \\
\text { and likely }\end{array}$ & $\begin{array}{l}\text { Lay summary } \\
\text { dictated by } \\
\text { consultant } \\
\text { familiar with }\end{array}$ & $\begin{array}{l}\text { Information in } \\
\text { summary will achieve } \\
\text { similar outcomes to } \\
\text { the consultant visit }\end{array}$ & Moderate & Low & $\begin{array}{l}\text { ICU consultant } \\
\text { to generate } \\
\text { summary }\end{array}$ & $\begin{array}{l}\text { ICU consultant } \\
\text { familiar with } \\
\text { topic guide, } \\
\text { knowledge of }\end{array}$ & General ward & $\begin{array}{l}\text { During post- } \\
\text { ICU hospital } \\
\text { stay }\end{array}$ \\
\hline
\end{tabular}


Table 4 Detailed description of the rehabilitation construct adapted from recommendations from wells and colleagues [29], the Medical Research Council framework [27], and the modified CONSORT guidance for randomised controlled trials of non-pharmacologic randomised controlled trials [28] (Continued)

\begin{tabular}{|c|c|c|c|c|c|c|c|c|c|c|}
\hline & & $\begin{array}{l}\text { problems during } \\
\text { recovery in } \\
\text { understandable } \\
\text { format }\end{array}$ & $\begin{array}{l}\text { patient history } \\
\text { using standard } \\
\text { proforma }{ }^{2}\end{array}$ & $\begin{array}{l}\text { and/or consolidate } \\
\text { information given }\end{array}$ & & & & $\begin{array}{l}\text { generic post-ICU } \\
\text { issues and the in- } \\
\text { dividual patient } \\
\text { history }\end{array}$ & & \\
\hline & & & & $\begin{array}{l}\text { Written summary can } \\
\text { be used as ongoing } \\
\text { resource by patient } \\
\text { and family }\end{array}$ & $\begin{array}{l}\text { All patients } \\
\text { provided with } \\
\text { summary, but } \\
\text { decision } \\
\text { regarding how } \\
\text { and when to } \\
\text { read this and } \\
\text { use it at patient } \\
\text { discretion }\end{array}$ & & $\begin{array}{l}\text { GRA to } \\
\text { provide it to } \\
\text { the patient, } \\
\text { often with } \\
\text { additional } \\
\text { explanation }\end{array}$ & $\begin{array}{l}\text { GRA with } \\
\text { relevant training } \\
\text { to assist patient } \\
\text { in understanding } \\
\text { content if } \\
\text { needed }\end{array}$ & & $\begin{array}{l}\text { Posted to } \\
\text { patient post- } \\
\text { discharge if } \\
\text { not available } \\
\text { prior to hos- } \\
\text { pital discharge }\end{array}$ \\
\hline & & & & $\begin{array}{l}\text { Important as poor } \\
\text { memory and other } \\
\text { cognitive impairments } \\
\text { may limit retention of } \\
\text { information from } \\
\text { meeting }\end{array}$ & & & & & & \\
\hline & $\begin{array}{l}\text { Provision of } \\
\text { self-help re- } \\
\text { habilitation } \\
\text { manual }\end{array}$ & $\begin{array}{l}\text { Provide a } \\
\text { resource to } \\
\text { support } \\
\text { recovery process }\end{array}$ & $\begin{array}{l}\text { Manual that } \\
\text { improved } \\
\text { physical } \\
\text { recovery in a } \\
\text { previous } \\
\text { randomised } \\
\text { controlled trial }^{3}\end{array}$ & $\begin{array}{l}\text { Supported use of the } \\
\text { self-help manual im- } \\
\text { proved physical func- } \\
\text { tion components of } \\
\text { quality of life question- } \\
\text { naires when used dur- } \\
\text { ing the first } 2 \text { months } \\
\text { following ICU } \\
\text { discharge }\end{array}$ & Moderate & High & GRA & $\begin{array}{l}\text { GRA familiar with } \\
\text { the content and } \\
\text { goals of the } \\
\text { manual }\end{array}$ & General ward & $\begin{array}{l}\text { Early during } \\
\text { the post-ICU } \\
\text { stay }\end{array}$ \\
\hline & & & & & $\begin{array}{l}\text { Manual } \\
\text { provided to all } \\
\text { patients }\end{array}$ & & & & & \\
\hline & & & & & $\begin{array}{l}\text { Use tailored to } \\
\text { individual } \\
\text { patients }\end{array}$ & & & & & \\
\hline $\begin{array}{l}\text { Stage two - } \\
\text { Ward-based } \\
\text { rehabilitation }\end{array}$ & $\begin{array}{l}\text { Regular } \\
\text { assessment by } \\
\text { GRA }\end{array}$ & $\begin{array}{l}\text { To assess } \\
\text { patients using a } \\
\text { combination of } \\
\text { clinical } \\
\text { judgement and } \\
\text { standardised } \\
\text { screening tools } \\
\text { in relation to: }\end{array}$ & $\begin{array}{l}\text { Frequent } \\
\text { assessment } \\
\text { and } \\
\text { reassessment }\end{array}$ & $\begin{array}{l}\text { A regular structured } \\
\text { approach by a single } \\
\text { individual to identify } \\
\text { problems across } \\
\text { multiple areas that } \\
\text { potentially contribute } \\
\text { to disability will } \\
\text { improve coordination } \\
\text { of care by senior } \\
\text { rehabilitation staff who } \\
\text { often working } \\
\text { separately }\end{array}$ & Moderate & Moderate & GRA & $\begin{array}{l}\text { GRA trained to } \\
\text { defined } \\
\text { competencies in } \\
\text { each area }\end{array}$ & General ward & $\begin{array}{l}\text { Throughout } \\
\text { acute hospital } \\
\text { stay }\end{array}$ \\
\hline
\end{tabular}

mportant as poor memory and other cognitive impairments may limit retention of meeting self-help re-

Provide

Use tailored to

patients

individual to iden

tentially contribute

o disability will

of care by senior

often working

separately patient pos

prior to hos-

often with

content

GRA familiar with General ward content and

during stay

goals of the

(1)


Table 4 Detailed description of the rehabilitation construct adapted from recommendations from wells and colleagues [29], the Medical Research Council framework [27] and the modified CONSORT guidance for randomised controlled trials of non-pharmacologic randomised controlled trials [28] (COninue

\begin{tabular}{|c|c|c|c|c|c|c|c|c|c|}
\hline & $\begin{array}{l}\text { Physical } \\
\text { function. } \\
\text { Nutritional } \\
\text { status and } \\
\text { dietary intake }\end{array}$ & $\begin{array}{l}\text { Use of } \\
\text { screening tools } \\
\text { to trigger } \\
\text { specialist advice } \\
\text { from: } \\
\text { physiotherapy, } \\
\text { dietetics, } \\
\text { occupational } \\
\text { therapy, and } \\
\text { speech and } \\
\text { language } \\
\text { therapy }^{4}\end{array}$ & $\begin{array}{l}\text { Consistency across } \\
\text { multiple relevant areas } \\
\text { will reduce the chance } \\
\text { of one unaddressed } \\
\text { issue slowing overall } \\
\text { recovery }\end{array}$ & $\begin{array}{l}\text { Frequency and } \\
\text { timing of } \\
\text { formal } \\
\text { assessments } \\
\text { and use of } \\
\text { screening tools } \\
\text { at discretion of } \\
\text { GRA, but } \\
\text { expected to } \\
\text { occur weekly }\end{array}$ & $\begin{array}{l}\text { Screening and } \\
\text { assessment } \\
\text { largely } \\
\text { undertaken by } \\
\text { GRA }\end{array}$ & & $\begin{array}{l}\text { GRA trained in } \\
\text { use of screening } \\
\text { tools }\end{array}$ & & \\
\hline & $\begin{array}{l}\text { Activities of } \\
\text { daily living }\end{array}$ & & & $\begin{array}{l}\text { Informal } \\
\text { assessment on } \\
\text { more frequent } \\
\text { basis }\end{array}$ & & & & & \\
\hline & $\begin{array}{l}\text { Communication } \\
\text { and swallowing }\end{array}$ & & & & & & & & \\
\hline \multirow[t]{4}{*}{$\begin{array}{l}\text { Individualised } \\
\text { goal setting }\end{array}$} & $\begin{array}{l}\text { To set achievable } \\
\text { realistic } \\
\text { rehabilitation } \\
\text { goals, } \\
\text { individualised to } \\
\text { each patient }\end{array}$ & $\begin{array}{l}\text { Documented } \\
\text { individualised } \\
\text { goals agreed } \\
\text { between } \\
\text { rehabilitation } \\
\text { team and } \\
\text { patient }\end{array}$ & $\begin{array}{l}\text { Individualised goal- } \\
\text { setting is effective in } \\
\text { other rehabilitation } \\
\text { settings }\end{array}$ & High & High & $\begin{array}{l}\text { GRAs and } \\
\text { senior } \\
\text { specialist } \\
\text { rehabilitation } \\
\text { staff as } \\
\text { necessary }\end{array}$ & $\begin{array}{l}\text { Training in the } \\
\text { use of goal- } \\
\text { setting in } \\
\text { rehabilitation } \\
\text { settings }\end{array}$ & General ward & $\begin{array}{l}\text { Throughout } \\
\text { acute hospital } \\
\text { stay }\end{array}$ \\
\hline & & $\begin{array}{l}\text { Regularly } \\
\text { revised }\end{array}$ & $\begin{array}{l}\text { Allows patient to focus } \\
\text { on issues important to } \\
\text { them }\end{array}$ & $\begin{array}{l}\text { Intention to } \\
\text { define } \\
\text { achievable } \\
\text { goals } \\
\text { approximately } \\
\text { weekly, but } \\
\text { adjusted to } \\
\text { individual } \\
\text { patients }\end{array}$ & & & & $\begin{array}{l}\text { Potentially } \\
\text { other settings } \\
\text { (home visits; } \\
\text { trips to other } \\
\text { areas) }\end{array}$ & \\
\hline & & & $\begin{array}{l}\text { Patient feels } \\
\text { empowered and } \\
\text { involved }\end{array}$ & & & & & & \\
\hline & & & $\begin{array}{l}\text { Achieving goals and } \\
\text { documenting progress } \\
\text { may have additional } \\
\text { beneficial effects on } \\
\text { psychological } \\
\text { morbidity }\end{array}$ & & & & & & \\
\hline $\begin{array}{l}\text { Therapy } \\
\text { sessions }\end{array}$ & $\begin{array}{l}\text { Provide therapy } \\
\text { sessions }\end{array}$ & $\begin{array}{l}\text { Individually } \\
\text { tailored }\end{array}$ & $\begin{array}{l}\text { Physiotherapy will } \\
\text { improve the }\end{array}$ & High & High & GRA & & General ward & \\
\hline
\end{tabular}


Table 4 Detailed description of the rehabilitation construct adapted from recommendations from wells and colleagues [29], the Medical Research Council framework [27], and the modified CONSORT guidance for randomised controlled trials of non-pharmacologic randomised controlled trials [28] (Continued)

\begin{tabular}{|c|c|c|c|c|c|c|c|c|c|}
\hline & $\begin{array}{l}\text { designed to } \\
\text { achieve } \\
\text { rehabilitation } \\
\text { goals }\end{array}$ & $\begin{array}{l}\text { therapy in } \\
\text { areas of: } \\
\text { Physiotherapy }\end{array}$ & $\begin{array}{l}\text { prominent } \\
\text { symptomatology, and } \\
\text { restore abilities to } \\
\text { undertake ADL }\end{array}$ & & & & $\begin{array}{l}\text { Competency- } \\
\text { based training in } \\
\text { all relevant areas }\end{array}$ & & $\begin{array}{l}\text { Throughout } \\
\text { acute hospital } \\
\text { stay }\end{array}$ \\
\hline & & Dietetics & $\begin{array}{l}\text { Dietetic therapy will } \\
\text { address weight loss } \\
\text { and barriers to } \\
\text { nutritional recovery, } \\
\text { such as poor appetite }\end{array}$ & & $\begin{array}{l}\text { Discrepancy } \\
\text { between } \\
\text { intended therapy } \\
\text { and treatment } \\
\text { achieved by } \\
\text { patient strongly } \\
\text { influenced by } \\
\text { patient fatigue, } \\
\text { mood, delirium, } \\
\text { and many other } \\
\text { issues }\end{array}$ & $\begin{array}{l}\text { Planning and } \\
\text { advice from } \\
\text { senior } \\
\text { rehabilitation } \\
\text { specialists }\end{array}$ & & $\begin{array}{l}\text { Physiotherapy } \\
\text { department }\end{array}$ & $\begin{array}{l}\text { Timing and } \\
\text { frequency } \\
\text { determined by } \\
\text { GRA and } \\
\text { rehabilitation } \\
\text { teams. Target } \\
\text { at least one } \\
\text { session per day } \\
\text { from GRA } \\
\text { monday to } \\
\text { friday }\end{array}$ \\
\hline & & $\begin{array}{l}\text { Occupational } \\
\text { therapy }\end{array}$ & $\begin{array}{l}\text { Occupational therapy } \\
\text { will restore ability to } \\
\text { undertake ADLs, } \\
\text { reduce disability, and } \\
\text { improve } \\
\text { independence }\end{array}$ & & & $\begin{array}{l}\text { Variable } \\
\text { amount of } \\
\text { therapy } \\
\text { provided by } \\
\text { senior } \\
\text { specialists } \\
\text { according to } \\
\text { individual } \\
\text { need }\end{array}$ & & $\begin{array}{l}\text { Occupational } \\
\text { therapy } \\
\text { department }\end{array}$ & \\
\hline & & $\begin{array}{l}\text { Speech and } \\
\text { language } \\
\text { therapy }\end{array}$ & $\begin{array}{l}\text { Speech and language } \\
\text { therapy will treat } \\
\text { specific swallowing } \\
\text { problems or } \\
\text { communication issues }\end{array}$ & & & & & $\begin{array}{l}\text { Other hospital } \\
\text { areas (stairs } \\
\text { and mobility) }\end{array}$ & \\
\hline & & $\begin{array}{l}\text { Pre-defined } \\
\text { sub-types of } \\
\text { therapy to cap- } \\
\text { ture the pro- } \\
\text { cesses that } \\
\text { occurred in } \\
\text { each session or } \\
\text { patient } \\
\text { encounter }\end{array}$ & $\begin{array}{l}\text { Coordinated approach } \\
\text { to therapy will reduce } \\
\text { disability, improve } \\
\text { quality of life, and may } \\
\text { decrease psychological } \\
\text { morbidity. }\end{array}$ & & & & & & \\
\hline $\begin{array}{l}\text { Offer visit to } \\
\text { the ICU }\end{array}$ & $\begin{array}{l}\text { May help with } \\
\text { memories and } \\
\text { adjustment to } \\
\text { health status }\end{array}$ & $\begin{array}{l}\text { Accompanied } \\
\text { visit to ICU } \\
\text { with GRA, } \\
\text { medical staff, } \\
\text { and family } \\
\text { according to } \\
\text { patient } \\
\text { preference }\end{array}$ & $\begin{array}{l}\text { ICU visit may help fill } \\
\text { in gaps for some } \\
\text { patients }\end{array}$ & High & High & $\begin{array}{l}\text { GRA plus } \\
\text { other staff } \\
\text { according to } \\
\text { patient } \\
\text { preference }\end{array}$ & $\begin{array}{l}\text { GRA familiar with } \\
\text { individual patient } \\
\text { history, and } \\
\text { trained in } \\
\text { common } \\
\text { psychological } \\
\text { morbidity and } \\
\text { memories of ICU }\end{array}$ & $\begin{array}{l}\text { ICU in which } \\
\text { patient was } \\
\text { cared for }\end{array}$ & $\begin{array}{l}\text { Any time } \\
\text { during acute } \\
\text { hospital stay, } \\
\text { or after } \\
\text { hospital } \\
\text { discharge if } \\
\text { preferred }\end{array}$ \\
\hline
\end{tabular}


Table 4 Detailed description of the rehabilitation construct adapted from recommendations from wells and colleagues [29], the Medical Research Council framework [27], and the modified CONSORT guidance for randomised controlled trials of non-pharmacologic randomised controlled trials [28] (Continued)

\begin{tabular}{|c|c|c|c|c|c|c|c|c|c|c|}
\hline & & & & $\begin{array}{l}\text { May help with } \\
\text { adjustment to illness } \\
\text { or dealing with } \\
\text { dreams and delusional } \\
\text { memories }\end{array}$ & $\begin{array}{l}\text { ICU visit } \\
\text { optional }\end{array}$ & & & & & \\
\hline & & & & $\begin{array}{l}\text { May reduce } \\
\text { psychological issues }\end{array}$ & $\begin{array}{l}\text { Timing to suit } \\
\text { individual } \\
\text { patient }\end{array}$ & & & & & \\
\hline \multirow[t]{2}{*}{$\begin{array}{l}\text { Stage three - } \\
\text { Hospital } \\
\text { discharge } \\
\text { planning }\end{array}$} & $\begin{array}{l}\text { Liaison with } \\
\text { ward-based } \\
\text { staff to ensure } \\
\text { equipment and } \\
\text { community re- } \\
\text { ferrals are in } \\
\text { place before } \\
\text { discharge } \\
\text { home }\end{array}$ & $\begin{array}{l}\text { Ensure services } \\
\text { and equipment } \\
\text { are in place } \\
\text { during the } \\
\text { transition from } \\
\text { hospital to the } \\
\text { community }\end{array}$ & $\begin{array}{l}\text { Liaison } \\
\text { between the } \\
\text { GRA and other } \\
\text { healthcare } \\
\text { professionals } \\
\text { to ensure } \\
\text { services and } \\
\text { equipment are } \\
\text { in place at } \\
\text { discharge }\end{array}$ & $\begin{array}{l}\text { Ensure patient has } \\
\text { correct services and } \\
\text { equipment in place at } \\
\text { home for discharge }\end{array}$ & Moderate & Moderate & $\begin{array}{l}\text { GRA and } \\
\text { other } \\
\text { healthcare } \\
\text { staff } \\
\text { depending on } \\
\text { patient needs }\end{array}$ & $\begin{array}{l}\text { GRA familiar with } \\
\text { patient history } \\
\text { and social/home } \\
\text { circumstance }\end{array}$ & General ward & $\begin{array}{l}\text { Throughout } \\
\text { ward stay to } \\
\text { allow planning } \\
\text { but in } \\
\text { particular in } \\
\text { the time } \\
\text { leading up to } \\
\text { discharge from } \\
\text { hospital }\end{array}$ \\
\hline & & & & $\begin{array}{l}\text { Ensuring patient is as } \\
\text { supported at possible } \\
\text { at the time of } \\
\text { discharge from } \\
\text { hospital }\end{array}$ & & & & & & \\
\hline \multirow[t]{4}{*}{$\begin{array}{l}\text { Stage four - } \\
\text { Post-hospital } \\
\text { discharge }\end{array}$} & $\begin{array}{l}\text { Provide contact } \\
\text { details for GRA }\end{array}$ & $\begin{array}{l}\text { A single point of } \\
\text { contact to } \\
\text { coordinate help } \\
\text { if patient not } \\
\text { coping in the } \\
\text { community }\end{array}$ & $\begin{array}{l}\text { Provide mobile } \\
\text { phone number } \\
\text { and advice to } \\
\text { contact if } \\
\text { required }\end{array}$ & $\begin{array}{l}\text { Many patients are } \\
\text { discharged home with } \\
\text { significant disability }\end{array}$ & Moderate & Moderate & GRA & $\begin{array}{l}\text { GRA familiar with } \\
\text { individual patient } \\
\text { case history }\end{array}$ & Community & $\begin{array}{l}\text { Following } \\
\text { hospital } \\
\text { discharge at } \\
\text { discretion of } \\
\text { GRA }\end{array}$ \\
\hline & $\begin{array}{l}\text { Telephone } \\
\text { patient at least } \\
\text { once following } \\
\text { discharge }\end{array}$ & & $\begin{array}{l}\text { A topic guide } \\
\text { to ensure all } \\
\text { issues are } \\
\text { covered }\end{array}$ & $\begin{array}{l}\text { Patients and families } \\
\text { often uncertain where } \\
\text { to turn for help }\end{array}$ & $\begin{array}{l}\text { All patients } \\
\text { and families } \\
\text { will receive } \\
\text { contact details }\end{array}$ & & & $\begin{array}{l}\text { Trained to } \\
\text { mobilise relevant } \\
\text { hospital and } \\
\text { community } \\
\text { teams as required }\end{array}$ & & $\begin{array}{l}\text { Unsolicited } \\
\text { contact within } \\
1 \text { week of } \\
\text { discharge }\end{array}$ \\
\hline & & & $\begin{array}{l}\text { Ensure any } \\
\text { equipment } \\
\text { and } \\
\text { community } \\
\text { referrals are in } \\
\text { place }\end{array}$ & $\begin{array}{l}\text { Single point of contact } \\
\text { to individual who } \\
\text { knows their history } \\
\text { well will enable rapid } \\
\text { identification of } \\
\text { problems and } \\
\text { solutions }\end{array}$ & $\begin{array}{l}\text { All patients } \\
\text { will receive } \\
\text { one } \\
\text { unsolicited } \\
\text { contact }\end{array}$ & & & & & $\begin{array}{l}\text { Ongoing } \\
\text { contact } \\
\text { available until } \\
\text { primary } \\
\text { outcome } \\
\text { measurement }\end{array}$ \\
\hline & & & & $\begin{array}{l}\text { This will reduce } \\
\text { patient/family stress, } \\
\text { decrease chance of } \\
\text { emergency }\end{array}$ & $\begin{array}{l}\text { Numbers of } \\
\text { subsequent } \\
\text { contacts } \\
\text { determined by }\end{array}$ & & & & & \\
\hline
\end{tabular}


Table 4 Detailed description of the rehabilitation construct adapted from recommendations from wells and colleagues [29], the Medical Research Council framework [27], and the modified CONSORT guidance for randomised controlled trials of non-pharmacologic randomised controlled trials [28] (Continued)

\begin{tabular}{|c|c|c|c|c|c|c|c|c|c|}
\hline & & & $\begin{array}{l}\text { readmission, and } \\
\text { improve efficiency of } \\
\text { use of community } \\
\text { rehabilitation teams }\end{array}$ & $\begin{array}{l}\text { patient and } \\
\text { family }\end{array}$ & & & & & \\
\hline \multirow[t]{4}{*}{$\begin{array}{l}\text { GP discharge } \\
\text { summary } \\
\text { (example } \\
\text { proforma } \\
\text { included in } \\
\text { Additional file 1) }\end{array}$} & $\begin{array}{l}\text { A discharge } \\
\text { summary } \\
\text { completed by } \\
\text { the GRA to } \\
\text { provide } \\
\text { additional } \\
\text { information to } \\
\text { GPs about the } \\
\text { impact of the } \\
\text { critical illness on } \\
\text { the patient }\end{array}$ & $\begin{array}{l}\text { A summary of } \\
\text { functional } \\
\text { ability across } \\
\text { physiotherapy, } \\
\text { occupational } \\
\text { therapy, } \\
\text { dietetics and } \\
\text { speech and } \\
\text { language } \\
\text { therapy }\end{array}$ & $\begin{array}{l}\text { GPs often only } \\
\text { manage } 1 \text { to } 2 \\
\text { patients a year that } \\
\text { suffer a critical illness }\end{array}$ & High & Low & GRA & $\begin{array}{l}\text { GRA familiar with } \\
\text { the individual } \\
\text { patient case } \\
\text { history and status } \\
\text { at the time of } \\
\text { discharge }\end{array}$ & $\begin{array}{l}\text { Office-based } \\
\text { activity }\end{array}$ & $\begin{array}{l}\text { Immediately } \\
\text { following } \\
\text { hospital } \\
\text { discharge }\end{array}$ \\
\hline & & $\begin{array}{l}\text { A short } \\
\text { summary of } \\
\text { psychological } \\
\text { function }\end{array}$ & $\begin{array}{l}\text { This information will } \\
\text { increase their } \\
\text { knowledge about the } \\
\text { specific issues faced by } \\
\text { the individual patient } \\
\text { after a critical illness }\end{array}$ & $\begin{array}{l}\text { All discharge } \\
\text { summary } \\
\text { letters will be } \\
\text { completed } \\
\text { with patient } \\
\text { specific detail }\end{array}$ & & & & & \\
\hline & & $\begin{array}{l}\text { A summary of } \\
\text { community } \\
\text { referrals made }\end{array}$ & $\begin{array}{l}\text { The additional general } \\
\text { information about } \\
\text { common sequelae } \\
\text { after critical illness will } \\
\text { increase the GPs } \\
\text { general knowledge of } \\
\text { the issues faced by } \\
\text { patients after critical } \\
\text { illness and facilitate } \\
\text { the identification of } \\
\text { any issues that arise } \\
\text { after discharge and } \\
\text { can be managed by } \\
\text { the GP }\end{array}$ & $\begin{array}{l}\text { All summaries } \\
\text { will include } \\
\text { standard } \\
\text { information } \\
\text { about the } \\
\text { general } \\
\text { sequelae after } \\
\text { critical illness }\end{array}$ & & & & & \\
\hline & & $\begin{array}{l}\text { Information } \\
\text { about typical } \\
\text { physical and } \\
\text { psychological } \\
\text { sequelae after } \\
\text { critical illness }\end{array}$ & & & & & & & \\
\hline
\end{tabular}

${ }^{1}$ Topic guides are available in Additional file 1. ${ }^{2}$ Proforma used to guide lay summary available in Additional file $1 .{ }^{3}$ Manual used was provided by the team that undertook the randomised controlled trial [20] and is in use in the National Health Service following the National Institute for Health and Care Excellence 83 recommendations [36]. ${ }^{4}$ The screening tools used are available in Additional file 1. ADLs, activities of daily living: GRA, generic rehabilitation assistant; GP, general practitioner. 
trial includes a full health economic evaluation over 12 months follow-up.

Our feasibility study and pre-trial work indicated that the intervention can be implemented in the NHS institutions in which the trial is ongoing (the two major adult hospitals within NHS Lothian, Scotland) [32,33]. We believe the magnitude of the problem (70,000 to 100,000 surviving patients annually in the UK ), the strong recommendations of NICE guideline 83 [36], likely costeffectiveness [56], and pressures on the acute healthcare sector mean widespread implementation of our complex intervention is likely if proved clinically and/or cost effective. We further believe that it will be widely practicable based on the information we have provided.

There are weaknesses to the methods used to develop our intervention. We did not undertake formal systematic reviews for the different components, although the incorporation of data from the NICE guideline development process reduced the risk of missing important evidence. A formal review of literature from other clinical settings (for example, the stroke or pulmonary rehabilitation literature) could have provided additional ideas for inclusion. We developed an intervention focussed on perceived needs of patients managed in the local healthcare setting, namely the UK NHS. The emphasis placed on locally acquired data could have introduced a researcher bias, although we attempted to minimise this through stakeholder involvement, and regular internal and external review. It is possible that our intervention may not address key needs in other healthcare systems, or may be addressing issues that are not relevant to those settings. This is difficult to avoid in complex intervention trials, where context is important, but justifies the need for careful description of intervention content and process. We did not use a pre-defined strategy for development, in part because the optimum methodology in this clinical setting is uncertain. MRC guidance [27] emphasises the importance of a cyclical iterative process when developing complex interventions. The 5-year cycle we used prior to embarking on a trial enabled modelling and piloting, but made the incorporation of emerging new data challenging. Ultimately, intervention development ended when several cycles of grant submissions resulted in a successful funding award. Several potential interventions were not included. These included controlled strategies during the period of mechanical ventilation in ICU, where interventions to increase mobilisation or maintain muscle activity show promise as strategies to decrease long-term functional disability [17-19]. Similarly, a formal exercise programme following hospital discharge was not included, although this was not effective in a recent trial [22]. Other issues that could have been addressed included management of delirium, sleep, and early traumatic memories. Our trial will evaluate the effectiveness of enhanced multidisciplinary rehabilitation focussed mainly on the acute hospital stay following ICU discharge. It may be difficult to exclude effect modification from other interventions that were not included or controlled. Despite this, both positive and negative trial results will inform future clinical practice and research design. In developing our intervention, a challenge was balancing the potential benefits of a more complex design over a longer time frame with the risk of greater protocol non-compliance, recruitment fatigue, and reduced capability to describe process in detail. These issues are challenging in this research field, but we believe they highlight the importance of clearly describing what was done in individual trials. A recent trial of enhanced physiotherapy following ICU admission had a longer term intervention during several stages of patient recovery, but failed to achieve adequate power as a result of low recruitment rates [23].

\section{Conclusions}

The development, implementation, and evaluation of complex interventions to promote recovery following critical illness are challenging. This detailed description of the intervention used in our trial using the principles set out in the MRC complex intervention framework [27] provide important additional information to the published protocol. This should help readers understand the trial results, maximise the external validity of the data, and help others implement the intervention, if proved clinically and cost-effective. Our detailed account of construct development and description provide a model for others undertaking similar complex intervention trials.

\section{Additional file}

Additional file 1: This document provides supplementary information to help increase the understanding of the context and content of the intervention delivered during the RECOVER trial.

\section{Abbreviations}

ADLs: activities of daily living; GDG: guideline development group; GRA: generic rehabilitation assistant; HRQoL: health-related quality of life; MRC: Medical Research Council; NHS: National Health Service; NICE: National Institute for Health and Care Excellence.

\section{Competing interests}

The authors declare that they have no competing interests.

\section{Authors' contributions}

TSW, LGS, JLM, PR and GH conceived the study and completed pilot and feasibility work. Specialist input to the study design and protocol development was provided by TSW, SJB and SJM (critical care perspective), LGS (physiotherapy/rehabilitation), PR and JER (nursing), JLM (dietetics), AMH (Psychiatrist in Psychotherapy), JFF (health economics), and GDM (study design and statistics). Advice on health service reorganisation aspects was provided by GH and SJM. All authors (with the exception of SJB) were involved in the acquisition of funding. All authors contributed to the drafting and revision of the paper. All authors read and approved the final manuscript. 


\section{Acknowledgements}

This study was funded by the Chief Scientist Office, Scotland. The authors wish to acknowledge Steff Lewis for her advice on statistical matters.

\section{Author details}

${ }^{1}$ Lothian University Hospitals Division, 51 Little France Crescent, Old Dalkeith Road, Edinburgh EH16 4SA, UK. ²Edinburgh Critical Care Research group, Edinburgh University and NHS Lothian, Chancellors Building, 49 Little France Crescent, Old Dalkeith Road, Edinburgh EH16 4SB, UK. ${ }^{3}$ Interdisciplinary Social Science in Health/Nursing Studies, University of Edinburgh, Medical School, Teviot Place (Doorway 6), Edinburgh EH8 9AG, UK. ${ }^{4}$ School of Nursing and Midwifery, University of Dundee, City Campus, 11 Airlie Place, Dundee DD1 4 HJ, UK. ${ }^{5}$ NHS Tayside, Perth Royal Infirmary, Perth PH1 1NX, UK. ${ }^{6}$ Imperial College Healthcare NHS Trust, The Bays, South Wharf Road, St Mary's Hospital, London W2 1NY, UK. 'Centre for Population Health Sciences, University of Edinburgh, Medical School, Teviot Place, Edinburgh EH8 9AG, UK. ${ }^{8}$ Centre for Inflammation Research, Queens Medical Research Institute, 47 Little France Crescent, Old Dalkeith Road, Edinburgh EH16 4TJ, UK.

Received: 24 June 2013 Accepted: 8 January 2014

Published: 29 January 2014

\section{References}

1. Herridge MS, Cheung AM, Tansey CM, Matte-Martyn A, Az-Granados N, Al-Saidi F, Cooper AB, Guest C, Mazer CD, Mehta S, Stewart TE, Barr A, Cook $D$, Slutsky AS: One-year outcomes in survivors of the acute respiratory distress syndrome. N Engl J Med 2003, 348:683-693.

2. Hofhuis JGM, Spronk PE, van Stel HF, Schrijvers GJP, Rommes JH, Bakker J: The impact of critical illness on perceived health-related quality of life during ICU treatment, hospital stay, and after hospital discharge - a long-term follow-up study. Chest 2008, 133:377-385.

3. van der Schaff M, Dettling DS, Beelen A, Lucas C, Dongelsmans DA, Nollett F: Poor functional status immediately after discharge from an intensive care unit. Disabil Rehabil 2008, 30:1812-1818.

4. Cuthbertson BH, Roughton S, Jenkinson D, MacLennan G: Quality of life in the five years after intensive care: a cohort study. Crit Care 2010, 14:R6.

5. Griffiths $\mathrm{RD}$, Jones $\mathrm{C}$ : $\mathrm{ABC}$ of intensive care - recovery from intensive care. Br Med J 1999, 319:427-429.

6. Cuthbertson BH, Hull A, Strachan M, Scott J: Post-traumatic stress disorder after critical illness requiring general intensive care. Intensive Care Med 2004, 30:450-455.

7. Myhren H, Ekeberg O, Toien K, Karlsson S, Stokland O: Posttraumatic stress, anxiety and depression symptoms in patients during the first year post intensive care discharge. Crit Care 2010, 14:R14

8. Brummel NE, Jackson JC, Girard TD, Pandharipande Schiro E, Work B, Pun PT, Boehm L, Gill TM, Ely EW: A combined early cognitive and physical rehabilitation program for people who are critically ill: the Activity and Cognitive Therapy in the Intensive Care Unit (ACT-ICU) trial. Physical Therapy 2012, 92:1580-1592.

9. Pandharipande PP, Girard TD, Jackson JC, Morandi A, Thompson JL, Pun BT, Brummel NE, Hughes CG, Vasilevskis EE, Shintani AK, Moons KG, Geevarghese SK, Canonico A, Hopkins RO, Bernard GR, Dittus RS, Ely EW, for the BRAIN-ICU Study Investigators: Long-term cognitive impairment after critical illness. N Eng J Med 2013, 369:1306-1316.

10. Cheung AM, Tansey CM, Tomlinson G, az-Granados N, Matte A, Barr A, Mehta S, Mazer CD, Guest CB, Stewart TE, Al-Saidu F, Cooper AB, Cook D, Slutsky AS, Herridge MS: Two-year outcomes, health care use, and costs of survivors of acute respiratory distress syndrome. Am J Respir Crit Care Med 2006, 174:538-544.

11. Paul F, Rattray J: Short- and long-term impact of critical illness on relatives: literature review. J Adv Nursing 2008, 62:276-292.

12. Denehy L, Berney S, Whitburn L, Edbrooke L: Quantifying physical activity levels of survivors of intensive care: a prospective observational study. Phys Ther 2012, 92:1507-1517.

13. Kelly MA, McKinley S: Patients' recovery after critical illness at early follow-up. J Clin Nursing 2012, 19:691-700.

14. Hopkins RO, Girard TD: Medical and economic implications of cognitive and psychiatric disability of survivorship. Semin Respir Crit Care 2012, 33:348-356.

15. Griffiths J, Hatch RA, Bishop J, Morgan K, Jenkinson C, Cuthbertson BH, Brett SJ: An exploration of social and economic outcome and associated health-related quality of life after critical illness in general intensive care unit survivors: a 12-month follow-up study. Crit Care 2013, 17:R100.

16. Lone N, Serenty M, Wild S, Rowan K, Murray G, Walsh TS: Surviving intensive care: a systematic review of healthcare resource use after hospital discharge. Crit Care Med 2013, 41:1832-1843.

17. Adler J, Malone D: Early mobilization in the intensive care unit: a systematic review. Cardiopulm Phys Ther 2012, 23:5-13.

18. Kayambu G, Boots R, Paratz J: Physical therapy for the critically ill in the ICU: a systematic review and meta-analysis. Crit Care Med 2013, 41:1543-1554.

19. Stiller K: Physiotherapy in intensive care: an updated systematic review. Chest 2013, 144:825-847.

20. Jones C, Skirrow P, Griffiths RD, Humphris GH, Ingleby S, Eddleston J, Waldmann C, Gager M: Rehabilitation after critical illness: a randomized, controlled trial. Crit Care Med 2003, 31:2456-2461.

21. Cuthbertson BH, Rattray J, Johnston M, Wildsmith JA, Wilson E, Hernendez R, Ramsey C, Hull AM, Norrie J, Campbell M: The PRaCTICaL study of nurse led, intensive care follow-up programmes for improving long term outcomes from critical illness: a pragmatic randomised controlled trial. BMJ 2009, 339:b4445.

22. Elliott D, McKinley S, Alison J, Aitken LM, King M, Leslie GD, Kenny P, Taylor P, Foley R, Burmeister E: Health-related quality of life and physical recovery after a critical illness: a multi-centred randomised controlled trial of a home-based physical rehabilitation programme. Crit Care 2011, 15:R142.

23. Denehy L, Skinner EH, Edbrooke L, Haines K, Warrillow S, Hawthorne G, Gough K, Hoorn SV, Morris ME, Berney S: Exercise rehabilitation for patients with critical illness: a randomized controlled trial with 12 months follow up. Crit Care 2013, 17:R156.

24. Wee HL, Cheung YB, Li SC, Fong KY, Thumboo J: The impact of diabetes mellitus and other chronic medical conditions on health-related quality of life: is the whole greater than the sum of its parts? Health Qual Life Outcomes 2005, 3:2.

25. Rijken M, Kerkhof M, Dekker J, Schellevis FG: Comorbidity of chronic diseases - effects of disease pairs on physical and mental functioning. Qual Life Res 2005, 14:45-55.

26. Kersten P, Ellis-Hill C, McPherson KM, Harrington R: Beyond the RCT understanding the relationship between interventions, individuals and outcome - the example of neurological rehabilitation. Clin Rehabil 2010, 32:1028-1034.

27. Craig P, Dieppe P, Macintyre S, Michie S, Nazareth I, Petticrew M: Developing and evaluating complex interventions: the new Medical Research Council guidance. BMJ 2008, 337:a1655.

28. Boutron I, Moher D, Altman DG, Schulz K, Ravaud P, for the CONSORT group: Extending the CONSORT Statement to randomized trials of nonpharmacologic treatment: explanation and elaboration. Ann Intern Med 2008, 148:295-309.

29. Wells M, Williams B, Treweek S, Coyle J, Taylor J: Intervention description is not enough: evidence from an in-depth multiple case study on the untold role and impact of context in randomised controlled trial of seven complex interventions. Trials 2012, 13:95.

30. Walsh TS, Salisbury LG, Boyd J, Ramsay P, Merriweather J, Huby G, Forbes J, Rattray JZ, Griffith DM, Mackenzie SJ, Hull A, Lewis S, Murray GD: A Randomised Controlled Trial Evaluating a Rehabilitation Complex Intervention Care Discharge. The RECOVER study. Br Med J 2012, 2:e001475.

31. Ramsay P: Quality of Life Following Prolonged Critical Illness: a Mixed Methods Study. Edinburgh: University of Edinburgh; 2011. https://www.era.lib.ed.ac. uk/handle/1842/8310.

32. Salisbury LG, Merriweather J, Walsh TS: The development and feasibility of a ward-based physiotherapy and nutritional package for people experiencing critical illness. Clin Rehabil 2010, 24:489-500.

33. Salisbury LG, Merriweather J, Walsh TS: Rehabilitation after critical illness: could a ward-based generic rehabilitation assistant promote recovery? Nurs Crit Care 2010, 15:57-65

34. James Lind Alliance Newsletter. [http://www.lindalliance.org/pdfs/JLA\% 20Newsletters/JLA_Affiliates_Newsletter_January_2011.pdf]

35. Cuthbertson BH, Scott J, Strachan M, Kilonzo M, Vale L: Quality of life before and after intensive care. Anaesthesia 2005, 60:332-339.

36. National Institute for Health and Care Excellence (NICE): Rehabilitation after critical illness pathway. 2009 [www.nice.org.uk/CG83]

37. Wehler M, Geise A, Hadzionerovic D, Aljukic E, Reulbach U, Hahn EG, Strauss $R$ : Health-related quality of life of patients with multiple organ dysfunction: individual changes and comparison with normative population. Crit Care Med 2003, 31:1094-1101. 
38. Iwashyna TJ, Ely EW, Smith DM, Langa KM: Long-term cognitive impairment and functional disability among survivors of severe sepsis. JAMA 2010, 304:1787-1794.

39. Orwelius L, Nordlund A, Nordland P, Simonsson E, Backman C, Samuelsson A, Sjoberg F: Pre-existing disease: the important factor for health related quality of life long-term after critical illness: a prospective, longitudinal, multicentre trial. Crit Care 2010, 14:R67.

40. Christiansen CF, Christiansen S, Johansen MB, Larsen KM, Tonnesen E, Sorensen HT: The impact of pre-admission morbidity level on 3-year mortality after intensive care: a Danish cohort study. Acta Anaesthesiol Scand 2011, 55:962-970.

41. Jones C, Griffiths RD, Humphris G, Skirrow PM: Memory, delusions, and the development of acute posttraumatic stress disorder-related symptoms after intensive care. Crit Care Med 2001, 29:573-580.

42. Rattray JE, Johnston M, Wildsmith JA: Predictors of emotional outcomes of intensive care. Anaesthesia 2005, 60:1085-1092.

43. Jackson JC, Hart RP, Gordon SM, Hopkins RO, Girard TD, Ely EW: Post-traumatic stress disorder and post-traumatic stress symptoms following critical illness in medical intensive care unit patients: assessing the magnitude of the problem. Crit Care 2007, 11:R27.

44. Wade DM, Howell DC, Weinman JA, Hardy RJ, Mythen MG, Brewin CR, Borja-Boluda S, Matejowsky CF, Raine RA: Investigating risk factors for psychological morbidity three months after intensive care: a prospective cohort study. Crit Care 2012, 16:R192.

45. Knowles RE, Tarrier $\mathrm{N}$ : Evaluation of the effect of prospective patient diaries on emotional well-being in intensive care unit survivors: a randomized controlled trial. Crit Care Med 2009, 37:184-191.

46. Jones C, Backman C, Capuzzo M, Egerod I, Flaatten H, Granja C, Rylander C Griffith RD: Intensive care diaries reduce new onset post-traumatic stress disorder following critical illness: a randomised controlled trial. Crit Care 2010, 14:R168.

47. Hopkins RO, Brett S: Chronic neurocognitive effects of critical illness. Curr Opin Crit Care 2005, 11:369-375.

48. Wolters AE, Slooter AJC, van der Kooi AW, van Dijk D: Cognitive impairment after intensive care unit admission: a systematic review. Intensive Care Med 2013, 39:376-386.

49. Schweickert WD, Pohlman MC, Pohlman AS, Nigos C, Pawlik AJ, Esbrook CL, Spears L, Miller M, Franczyk M, Deprizio D, Schmidt GA, Bowman A, Barr R, McCallister KE, Hall JB, Kress JP: Early physical and occupational therapy in mechanically ventilated, critically ill patients: a randomised controlled trial. Lancet 2009, 373:1874-1882.

50. Morris PE, Goad A, Thompson C, Taylor K, Harry B, Passmore L, Ross A, Anderson L, Baker S, Sandez M, Penley L, Howard A, Dixon L, Leach S, Small R, Hite $D$, Haponite E: Early intensive care care unit mobility therapy in the treatment of acute respiratory failure. Crit Care Med 2008, 36:2238-2243.

51. Burtin C, Clerckx B, Robbeets C, Ferdinade P, Langer D, Troosters T, Hermans G, Decramer M, Gosselink R: Early exercise in critically ill patients enhances short-term functional recovery. Crit Care Med 2009, 37:2499-2505.

52. Scottish Intensive Care Society Audit Group: Audit of critical care in Scotland 2011. Reporting on 2010. http://www.sicsag.scot.nhs.uk/Publications/SICSAGreport_2011-webversion.pdf (Accessed 26 November 2013).

53. Sacanella E, Perez-Castejon JM, Nicolas JM, Masanes F, Navarro M, Castro P, Lopez-Soto A: Functional status and quality of life 12 months after discharge from a medical ICU in healthy elderly patients: a prospective observational study. Crit Care 2011, 15:R105.

54. Smith R, Duffy J: Developing a competent and flexible workforce using the Calderdale Framework. Int I Ther Rehabil 2010, 17:254-262

55. World Health Organization (WHO): International classification of functioning. Geneva: WHO; 2010.

56. National Institute for Health and Clinical Excellence (NICE): Rehabilitation after Critical Illness: Costing report - Implementing NICE Guidance. 2009. http://www.nice. org.uk/nicemedia/live/12137/44100/44100.pdf (Accessed 26 November 2013).

doi:10.1186/1745-6215-15-38

Cite this article as: Ramsay et al:: A rehabilitation intervention to promote physical recovery following intensive care: a detailed description of construct development, rationale and content together with proposed taxonomy to capture processes in a randomised controlled trial. Trials 2014 15:38.

\section{Submit your next manuscript to BioMed Central and take full advantage of:}

- Convenient online submission

- Thorough peer review

- No space constraints or color figure charges

- Immediate publication on acceptance

- Inclusion in PubMed, CAS, Scopus and Google Scholar

- Research which is freely available for redistribution 